\title{
ASPEK HUKUM DALAM PELAKSANAAN ADMINISTRASI PUBLIK DI INDONESIA
}

\author{
Evi Oktarina, Liza Deshaini, Bambang Sugianto \\ Sekolah Tinggi Ilmu Hukum Sumpah Pemuda \\ evioktarina255@gmail.com, lizadeshaini69@gmail.com, \\ bambangsugianto1969@gmail.com
}

\begin{abstract}
ABSTRAK
Bentuk dari aspek hukum dalam pelaksanaan administrasi publik di Indonesia adalah kebijakan publik dapat ditinjau tidak hanya secara sosial, politik dan ekonomi tetapi juga yuridis (perundang-undangan). Tujuannya agar penyusunan kebijakan tidak sembarangan atau benar-benar mempertimbangkan dalam menyusun kebijakan akan tidak dianggap melakukan tindakan sewenang-wenang melanggar kewenangan atau mengacuhkan kepentingan publik. Fungsi pemerintah dalam membuat kebijakan dibidang hukum adminstrasi publik yaitu fungsi regeling, membuat produk hukum tertulis yang berisikan materi daya ikat terhadap sebagian atau seluruh penduduk wilayah Negara dan fungsi beschikking, produk hukum yang berupa penetapan yang dibuat oleh pejabat tata usaha Negara.
\end{abstract}

Kata kunci: Aspek Hukum, Administrasi Publik, Pemerintahan.

\section{ABSTRACT}

The form of the legal aspect in the implementation of public administration in Indonesia is that public policy can be reviewed not only socially, politically and economically but also juridically (legislation). The aim is that the formulation of policies is not carelessly or truly considerate in formulating policies that will not be considered as having arbitrarily violated authority or ignored the public interest.The function of the government in making policies in the field of public administration law is the function of regeling, making written legal products containing material binding power to part or all of the population of the State territory and the beschikking function, legal products in the form of decisions made by state administrative officials.

\section{Keywords: Legal Aspects, Public Administration, Government.}

\section{A. Pendahuluan}

Negara merupakan sebuah organisasi politik karena merupakan tata aturan yang mengatur penggunaan paksaan dan Negara memonopoli penggunaan paksaan tersebut. Selain itu, Negara adalah suatu masyarakat yang diorganisasikan secara politik dan merupakan suatu komunitas yang ditentukan oleh suatu tata aturan yang sifatnya memaksa. Tata aturan yang memaksa tersebut adalah hukum.

Dalam konteks ini, Negara dipandang sebagai institusi yang legalistik dan normatif. Pandangan ini menempatkan Negara sebagai lembaga yang state centrist.
Bahwa segala hal yang tersedia dalam Negara merupakan kebijakan yang didasarkan pada pertimbangan pejabat publik atau administrasi Negara. Peranan dan ruang partisipasi masyarakat, publik atau non-negara sangat minim serta dibatasi.

Konsep Negara yang demikian sudah banyak mendapat kritik. Kritik yang dilontarkan oleh para penentang pendekatan terpusat yang tertumpu pada Negara. Kritik tersebut muncul karena mereka melihat semakin pentingnya aktor-aktor lain di luar Negara. Sedangkan kritik yang dating dari pendekatan individu berangkat dari kekhawatiran terjadinya manipulasi oleh 
sekelompok elit kekuasaan yang mengklaim bahwa kepentingannya itu ditujukan untuk ke-pentingan Negara. ${ }^{1}$

Meskipun definisi Negara dapat berbeda-beda tergantung pada sudut pandangnya, namun terdapat pandangan yang sama dan umum mengenai tujuan dan makna dari keberadaan sebuah Negara dan pemerintahan bagi warga Negara atau rakyatnya. Setiap Negara, apapun ideology yang dianutnya menyelenggarakan fungsi minimum yang mutlak sifatnya, yaitu: a) melaksanakan penerbitan (law and order); b) mengusahakan kesejahteraan dan kemakmuran rakyatnya; c) melaksanakan fungsi pertahanan; d) menegakkan keadilan. Untuk menjalankan fungsi-fungsi tersebut, maka diperlukan adanya badan pemerintah. Pemerintahan yang selanjutnya akan mewakili Negara dalam membangun hubungan dengan warga negaranya.

Beragam dan berkembangnya fungsi Negara menyebabkan perkembangan atas fungsi dan unsur pemerintahan, pemerintahan modern saat ini sudah jauh berbeda dengan model pemerintahan pada jaman Negara klasik. Pemerintah adalah institusi yang keberadaannya mendahului Negara. Pemerintah adalah orang atau sekelompok orang yang memerintah dan mengelola komunitas politik atas Negara, agar pemerintah terwujud harus ada eksistensi dari Negara. Kehadiran Negara semakin menjadikan pemerintah sebagai elemen administrasi yang mapan. Oleh karena itu, tiada Negara tanpa pemerintahan. ${ }^{2}$

Pemerintahan adalah sebuah organisasi yang mengelola sebuah Negara atau bagian dari suatu Negara. Beberapa pengertian dan pemahaman lainnya mengenai pemerintahan, antara lain:

1. Van Poelje (Hamdi, 2002) menjelaskan bahwa pemerintahan da-

Sosialismanto, Hegemoni Negara Ekonomi Politik Pedesaan Jawa, Lapera Pustaka Utama, Yogyakarta, 2001, hal.3

${ }^{2}$ Chandran Kukathas, A Definition of the State, University of Queensland Law Jornal, Australi, 2014, hal. 357-366 pat dipandang sebagai suatu ilmu yang mengajarkan bagaimana cara terbaik dalam mengarahkan dan memimpin pelayanan umum.

2. Wodrrow Wilson, pemerintah merupakan wujud yang kompleks sesuai dengan asal mula atau sejarah mereka yang khas: keadaan yang telah membentuk mereka, kebutuhan, minat atau prilaku yang telah banyak membimbing mereka.

3. Menurut A. Abdulkarim, pemerintahan adalah segala urusan yang dilakukan oleh Negara dalam menyelenggarakan kesejahteraan rakyat dan kepentingan Negara.

Tanpa pemerintah, Negara tidak akan bekerja dan hanya akan menjadi institusi yang statis. Keberadaan Negara merupakan perpanjangan tangan dari fungsi dan tujuan Negara. Oleh karena itu, pemerintah akan tetap ada selama Negara itu berdiri. Salah satu institusi pemerintah yang paling tua dalam sejarah, sehingga birokrasi dan administrasi dapat dianggap setua peradaban manusia itu sendiri, di mana salah satu mempengaruhi yang lain, sehingga pada akhirnya terjalin hubungan yang erat antara peradaban manusia dengan administrasi-nya.

Guna menjalankan perannya dalam mewujudukan tujuan Negara, pemerintah memiliki beberapa fungsi, yaitu primer dan sekunder.

Fungsi primer dibedakan menjadi dua, yaitu fungsi pelayanan dan fungsi pengaturan. Fungsi pertama berarti bahwa fungsi utama pemerintah adalah memberikan pelayanan terbaik untuk memenuhi kebutuhan masyarakat disemua sektor. Masyarakat tak dapat berdiri sendiri memenuhi kebutuhan tanpa adanya pemerintah yang memberikan pelayanan. Ini merupakan fungsi yang bersifat umum dan dilakukan oleh seluruh Negara di dunia. Fungsi kedua mengenai pemerintah yang mengatur seluruh sektor dengan kebijakan-kebijakan dalam bentuk Undang-Undang, Peraturan Pemerintah, dan peraturan lainnya. Maksud 
penyelenggaraan fungsi kedua adalah untuk menjaga stabilitas Negara dan menjamin pertumbuhan Negara sesuai yang diinginkan.

Fungsi sekunder dibedakan men-jadi beberapa jenis, yaitu :

1. Fungsi pembangunan : fungsi ini dijalankan apabila kondisi masyarakat melemah dan pembangunan dikontrol ketika masyarakat membaik.

2. Fungsi pemberdayaan : fungsi ini diselenggarakan dalam rangka untuk membangun masyarakat agar menjadi lebih mandiri dan berdaya sehingga masyarakat tidak selalu bergantung pada pemerintah.

Fungsi utama dari pemerintah saat ini adalah pembangunan kualitas kehidupan masyarakat dan mengurangi kemiskinan. Namun kedua fungsi utama tersebut tidak dapat dibangun sendiri tanda adanya fondasi ekonomi yang mapan. Oleh karena itu, fungsi utama yang pertama harus dilakukan adalah membangun berkelanjutan ekonomi dan pembangunan sosial masyarakat.

Pada abad ke-21, ada 4 (empat) peran penting yang pertama dapat digunakan oleh pemerintah untuk mencapai pembangunan ekonomi dan sosial yang berkelanjutan. Hal terpenting dari peran ini adalah mengembangkan kapasitas kelembagaan karena dapat menciptakan konteks dan landasan bagi kondisi yang lain. Tanpa institusi yang kuat, baik pemerintah maupun sektor swasta tidak dapat merangsang pertumbuhan ekonomi atau kemajuan sosial.

Peran penting kedua adalah memberlakukan dan menerapkan kebijakan yang menciptakan lingkungan yang mendukung partisipasi efektif dalam ekonomi global. Ketidakmampuan beberapa Negara untuk mendapatkan keuntungan dari interaksi ekonomi internasional amat berpotensi menghambat pencapaian kemajuan ekonomi atau sosial. Ketiga, untuk mencapai pertumbuhan ekonomi yang setara secara sosial, pemerintah harus fokus pada kebijakan yang setara secara miskin untuk memerangi kemiskinan dan meningkatkan kapasitas orang-orang yang biasanya tidak memperoleh manfaat dari pertumbuhan ekonomi kearah partisipasi yang lebih efektif dalam kegiatan produktif.

Keempat, pemerintah memiliki peran penting dalam memperkuat kappasitas administrasi publik untuk meningkatkan pertumbuhan ekonomi secara sosial, memungkinkan partisipasi dalam ekonomi global dan memerangi kemiskinan. UndangUndang Nomor 30 Tahun 2014 tentang Administrasi Pemerintahan, mengatur fungsi pemerintahan meliputi fungsi pengaturan, pelayanan, pembangunan, pemberdayaan dan perlindungan.

Dalam melaksanakan fungsi tersebut kepada badan/pejabat pemerintahan diberikan kewenangan untuk membuat keputusan dan melaksanakan tindakan pemerintah yang dimaksud dengan kewenangan pemerintahan adalah kekuasaan badan dan/atau pejabat pemerintahan atau penyelenggaraan Negara lainnya untuk bertindak dalam ranah hukum publik. ${ }^{3}$

Perkembangan peran pemerintahan sebagai tugas-tugas Negara/ pemerintahan yang modern, di mana pada umumnya pilihan dari tugas-tugas yang modern tersebut bergantung pada: ${ }^{4}$

a. Kesukaran dan kebutuhan yang didasarkan oleh masyarakat yang bersangkutan.

b. Sarana-sarana keuangan dan kemungkinan lain yang bersedia untuk menjalankan tugas-tugas tertentu.

c. Tanggapan dibidang politik tentang kebijaksanaan Negara yang diinginkan.

d. Kewajiban-kewajiban pada tingkat internasional.

\footnotetext{
${ }^{3}$ Indroharto, Usaha Memahami UndangUndang tentang Peradilan Tata Usaha Negara, Sinar Grafika, Jakarta, 1993, hal.83

${ }^{4}$ Philipus M. Hardjon, Pengantar Hukum Administrasi Indonesia, UGM Perss, Yogyakarta, 1994, hal. 8
} 
Kompleksitas peranan dan fungsi pemerintah modern saat ini memberikan konsekuensi kepada penataan modern penyelenggaraan pemerintahan dalam konteks penyusunan kelembagaan. Pemerintah tidak dapat lagi menjadi satu-satunya pihak yang berkewajiban untuk menyediakan semua kebutuhan bagi masyarakat. Hal tersebut bukan dimaksudkan untuk mengurangi atau bahkan menghilangkan peran pemerintah dan Negara bagi masyarakatnya, sebab $\mathrm{Ne}$ gara dan pemerintah ada karena dari masyarakatnya. Oleh karenanya Negara dan pemerintah tetap menjadi pelayanan atau abdi Negara bagi rakyatnya.

\section{B. Permasalahan}

1. Apa saja bentuk aspek hukum dalam Pelaksanaan Administrasi Publik di Indonesia?

2. Bagaimana Fungsi Pemerintah dalam membuat Kebijakan dibidang Hukum Administrasi ?

\section{Metode Penelitian}

Sesuai dengan ruang lingkup dan permasalahan yang dikemukakan, maka penelitian ini termasuk dalam jenis penilitian hukum normatif yang bersifat deskriptif. Analisa difokuskan dari segi hukum yang bersifat teoritis normatif, artinya kajian-kajian hanya didasarkan atas aspek teoritis dengan menganalisa berbagai aspek yang berkaitan dengan pokok permasalahan.

\section{Pembahasan}

\section{Bentuk Aspek-aspek Hukum dalam Pelaksanaan Administrasi Publik di Indonesia}

Konsep administrasi publik telah berkembang dari waktu ke waktu. Perkembangan tersebut disebabkan banyak faktor, baik internal maupun eksternal dan global. Pengertian dan dimensi administrasi publik klasik dan modern sudah tentu amat berbeda. Orientasi penyelenggaraannya pun berbeda. Berawal dari paradigma administrasi Negara di mana konsentrasi maupun orientasi penyelenggaraan pemerintahan didasarkan pada fungsi dan keberadaan Negara atau pemerintah.

Agar dapat memahami fungsi dan ruang lingkup administrasi publik, maka perlu diuraikan terlebih dahulu mengenai pengertian atau batasan administrasi publik.

1) Administrasi publik atau administrasi Negara adalah suatu bahasan ilmu sosial yang mempelajari tiga elemen penting kehidupan bernegara yang meliputi lembaga legislatif, yudikatif dan eksekutif serta hal-hal yang berkaitan dengan publik yang meliputi kebijakan publik, manajemen publik, administrasi pembangunan, tujuan Negara dan etika mengatur penyelenggara Negara. ${ }^{5}$

2) Menurut Marune, administrasi publik merupakan aspek bidang adminitrasi yang lebih luas dan berada dalam sistem politik gunamencapai tujuan serta sasaran yang dirumuskan oleh pengambilan keputusan politik. Hal ini juga dikenal sebagai administrasi pemerintah karena ada sifat publik dalam kata administrasi publik berarti pemerintahan. Oleh karena itu, fokus administrasi publik adalah pada birokrasi publik, yaitu organisasi birokrasi pemerintah.

3) Dwight Waldo, menyatakan administrasi publik sebagai seni dan ilmu manajemen yang diterapkan pada urusan Negara. Proses administrasi publik terdiri dari tindakan yang terlibat dalam mempengaruhi maksud dan keinginan pemerintah. Dengan demikian, bagian proses yang terus aktif dan pemerintah terkait dengan pelaksanaan

\footnotetext{
5 Surie, Ilmu Administrasi Negara, Gramedia, Jakarta, 1986, hal. 10
} 
Undang-Undang yang dibuat oleh badan legislatif serta ditafsirkan oleh pengadilan melalui proses organisasi dan manajemen. ${ }^{6}$

4) Menurut Undang-Undang tentang administrasi pemerintahan, adalah tata laksana dalam pengambilan keputusan dan/atau tindakan oleh badan dan/atau pejabat pemerintah.

Khusus di Indonesia, hukum administrasi Negara telah banyak mengalami perluasan bidang kajian dan substansi pengaturan yang tidak lagi berpatokan pada peran Negara. Namun termasuk pula peran lembaga non-pemerintah dan bahkan dunia usaha terkait dengan fungsi kesejahteraan serta layanan publik. Perluasan bidang tersebut diakibatkan oleh meluasnya bidang penyelenggaraan pemerintah, rezim keuangan yang luas, dan perkembangan model atau pola tata laksana pemerintahan, maupun keterlibatan aktif dunia usaha terha-dap bidang politik publik.

Hukum administrasi menentukan batasan kewenangan yang didelegasikan kepada instansi pemerintah, dan UndangUndang tersebut menyediakan pengadilan alat untuk memantau pelaksanaan kewenangan tersebut. Kondisi ini terkait dengan popularitas konsep democratic government yang mungkin sudah diterapkan oleh semua Negara termasuk di Indonesia. Konsekuensinya adalah semua perwakilan demokrasi pasti menghadapi kebutuhan untuk menyeimbangkan akuntabilitas demokratis terhadap penerapan Undang-Undang yang dilaksanakan oleh cabang kekuasaan eksekutif melalui badan administrasinya.

Perkembangan hukum administrasi umum yang sedang giat dilaksanakan dibanyak Negara bergerak dalam tiga taraf secara berturut-turut, yaitu :

1) Pada mulanya perkembangan hukum administrasi umum itu

6 Dwight Waldo, Pengantar Studi Publik Administration, Aksara Baru, Jakarta, 1991, hal.40 hanya merupakan suatu perkembangan dalam ilmu pengetahuan itu sendiri.

2) Perkembangan kedua yang penting dimulai dengan diperkenalkannya peradilan administrasi Negara.

3) Perkembangan yang ketiga timbul manakala pembuat UndangUndang memutuskan dengan tujuan menyelaraskan tindakantindakan pemerintah untuk mengadakan pembuatan UndangUndang umum.

Dalam konteks democratic government dan rule of law peran dan fungsi pemerintah diatur dan dilaksanakan berdasarkan peraturan perundang-undangan atau hukum dalam arti luas. Pelaksanaan administrasi publik tanpa regulasi yang menyetujuinya akan menyebabkan perbuatan atau kebijakan yang diambil menjadi illegal. Fungsi pengaturan dalam administrasi publik bukan hanya sebagai panduan atau pedoman pelaksanaan tetapi juga sebagai instrument akuntabilitas bagi administrasi publik.

Dalam konteks inilah relasi antara hukum dan administrasi publik menjadi terjalin. Administrasi publik tidak dapat berjalan di luar rambu-rambu regulasi. Namun di sisi lain, fungsi dan peran yang telah dimandatkan oleh hukum kepada administrasi publik tidak boleh diabaikan disampingi dan dikurangi.

Menurut C.F. Strong dalam Budiardjo, administrasi publik sebagai refresentasi dari cabang eksekutif memiliki sejumlah kewenangan dalam beberapa bidang, yaitu: ${ }^{7}$

a. Administrasi, yakni kekuasaan untuk melaksanakan UndangUndang dan peraturan perundangan lainnya dan menye-

\footnotetext{
${ }^{7}$ Miriam Budiardjo, Dasar-dasar Ilmu Politik, Gramedia, Jakarta, 2003
} 
lenggarakan administrasi Negara.

b. Legislasi, yakni membuat rancangan Undang-Undang dan membimbingnya dalam badan perwakilan rakyat sampai menjadi Undang-Undang.

c. Keamanan, yakni kekuasaan untuk mengatur polisi dan angkatan bersenjata, menyelenggarakan perang, pertahanan $\mathrm{Ne}$ gara serta keamanan dalam negeri.

d. Yudikatif, memberi grasi, amnesti dan sebagainya.

e. Diplomatik, yakni kekuasaan untuk menyelenggarakan hubungan diplomatik dengan Negara-negara lain.

Sebagai akibat luasnya bidang pekerjaan dan tanggungjawab dari administrasi publik terutama dalam bidang penyelenggaraan kesejahteraan bagi masyarakat, maka kepada administrasi publik dilekatkan pula kewenangan dalam membuat peraturan. Kewenangan ini merupakan bentuk kewenangan yang didelegasikan dari parlemen kepada badan administrasi publik.

Pada prinsipnya, pihak yang membuat kebijakan juga mempunyai kewenangan untuk melaksanakan kebijakan tersebut. Hal yang juga penting untuk dipahami adalah setiap kebijakan publik terkandung aspek yuridis di dalamnya, sehingga tidak dapat hanya dianggap sebagai produk politik dan administrasi saja. Sebagai instrument yang beraspek yuridis, maka sebagai konsekuensi yuridis pula dalam setiap kebijakan terkandung hak dan kewajiban yuridis yang dimiliki subjek hukum masyarakat (sebagai pihak yang diatur) dan administrasi publik (sebagai subjek hukum yang mengatur).

Ada beberapa bentuk aspek-aspek hukum dalam pelaksanaan administrasi publik, antara lain :

a. Kebijakan publik harus dibuat tidak hanya berdasarkan prinsipprinsip dalam ilmu administrasi publik, namun juga dalam ilmu hukum(perundang-undangan), seperti didasarkan pada kewenangan, memenuhi legal procedure pada tahap penyusunan hingga pemberlakuan dan tidak saling bertentangan.

b. Kebijakan publik tidak hanya memiliki implikasi sosial, ekonomi dan politik, tetapi juga yuridis. Lahirnya suatu kebijakan akan memberikan hak dan kewajiban yuridis bagi pihak yang terkena. Oleh karena itu, kebijakan secara otomatis akan memiliki daya paksa dan daya laku. Pihak yang melanggarnya akan terkena sanksi sebagaimana diatur dalam kebijakan tersebut.

c. Kebijakan publik akan melahirkan status hukum yang baru bagi pihak-pihak yang terkena, status hukum yang positif (dalam artian mem-berikan hak-hak baru) atau negatif (membebankan kewajibankewajiban baru), gejolak sosial pasti akan muncul akibat lahirnya suatu kebijakan, sehingga akan terlihat bagaimana efektifitas dari kebijakan tersebut.

d. Kebijakan publik dapat ditinjau tidak hanya secara sosial, politik dan ekonomi tetapi juga yuridis. Sebagai produk hukum, maka kebijakan publik dapat ditinjau atau digugat secara yuridis. Konsekuensinya adalah kebijakan tersebut dapat dicabut atau dibatalkan keberlakuannya.

\section{Fungsi Pemerintah dalam Membuat Kebijakan di Bidang Hukum Admi- nistrasi Publik}

Untuk menjalankan tugas-tugas pelayanan publik, admnistrasi publik memang perlu dilekati dengan fleksibilitas melalui kewenangan diskresi. Hal itu sebagai konsekuensi logis agar proses penyediaan publik tidak terhambat oleh banyak prosedur dan regulasi, terutama atas kepentingan 
umum yang mendesak. Akan tetapi dalam pelaksanaannya, haruslah tindakan-tindakan administrasi publik tersebut sesuai dengan hukum. Hal ini berarti, dalam menjalankan tugasnya secara aktif administrasi publik harus dapat menjaga dan menjamin bahwa tindakan-tindakannya tidak melanggar hak dan kewajiban asasi manusia. ${ }^{8}$

Karena itu, dapat disimpulkan bahwa tugas pokok dari keberadaan hukum administrasi adalah untuk memberikan kontrol hukum terhadap pelaksanaan kekuasaan administratif, yang diberikan pada berbagai lembaga administratif untuk segala macam tujuan yang berbeda. Kontrol terhadap segala tindakan dan keputusan administrasi publik harus didasarkan pada makna yang benar dari kepentingan umum/publik. ${ }^{9}$

Sudah menjadi pandangan umum bahwa penyakit administratif atau birokrasi di antaranya adalah penyalahgunaan jabatan, penyelenggaraan kekuasaan, ketidakadilan dalam memberikan pelayanan publik atau berbelit-belit pelayanan dalam birokrasi yang semuanya amat mungkin disebabkan oleh konflik kepentingan dalam diri aparatur itu sendiri dan manajemen dalam rangka pengelola administrasi Negara. ${ }^{10}$

Pemerintah yang berhasil merupakan pemerintah yang baik (good government). Good governance sendiri dapat diukur setidaknya melalui dua pendekatan, yaitu pendekatan politik dan pendekatan ekonomi. Pendekatan politik bahwa pemerintah memberikan keamanan dan Kenyamanan bagi masyarakatnya. Rasa aman dan nyaman tersebut dapat dirasakan dalam segala bidang terutama yang menyangkut hak-hak dasar sebagai warga Negara.

${ }^{8}$ Syahran Basah, Eksistensi dan Tolak Ukur Peradilan Administrasi di Indonesia, Alumni, Bandung, 1985, hal. 151

9 Hamzah dan Lopa, Mengenal Peradilan Tata Usaha Negara, Sinar Grafika, Jakarta, 1993, hal. 67

10 Adrian Sutedi, Hukum Perizinan dalam Sektor Pelayanan Publik, Sinar Grafika, Jakarta, 2010, hal. 23
Untuk mengukur pemerintahan itu termasuk good governance atau tidak ada beberapa ukuran yang dapat dipakai. Kualitas pemerintahan dapat dibagi ke dalam 6 (enam) kategori yang melihat pemerintah melalui bagaimana pemerintah itu dipilih, diawasi, digantikan, bagaimana kapasitas pemerintah dalam menyusun dan melaksanakan kebijakan dan bagaimana respek dari warga Negara terhadap pemerintah. Indikator-indikator tersebut, yaitu :

a. Suara dan akuntabilitas

b. Stabilitas politik dan minim-nya kekerasan

c. Efektivitas pemerintahan

d. Kualitas regulasi yang diciptakan

e. Penegakan hukum

f. Kontrol terhadap korupsi. ${ }^{11}$

Pemerintah yang baik adalah pemerintahan yang dapat diawasi dan dikontrol oleh semua elemen Negara, baik pemerintah itu sendiri dan terlebih utama oleh masyarakat. Pengawasan amat diperlukan agar pelaksanaan penyelenggaraan pemerintahan dapat berjalan sesuai dengan visi, misi dan tujuannya. Selain itu, pengawasan digunakan untuk memastikan agar penyelenggaraan pemerintahan tidak berjalan berdasarkan kepentingan politik elit saja atau sekelompok orang tertentu yang memiliki pengaruh secara politik.

Dalam tindakan pengawasan harus terpenuhi beberapa unsur penting, yaitu: ${ }^{12}$

a. Adanya kewenangan yang jelas yang dimiliki oleh pejabat pengawas.

b. Adanya rencana yang jelas sebagai alat penguji terhadap pelaksanaan suatu tugas yang akan diawasi.

c. Tindakan pengawasan dapat dilakukan terhadap suatu proses kegia-

11 Sharma, Democracy, Good Governance, and Economic Development, Journal of Democracy, Taiwan, 2007, hal. 29

12 Muchsan, Sistem Pengawasan terhadap Perbuatan Aparat Pemerintah dan Peradilan Tata Usaha Negara di Indonesia, Liberty, Yogyakarta, 1986, hal. 69 
d. tan yang sedang berjalan maupun terhadap hasil yang dicapai.

e. Tindakan pengawasan berakhir dengan disusunnya evaluasi akhir terhadap kegiatan yang dilaksanakan serta pencocokan hasil yang dicapai dengan rencana sebagai tolak ukurnya.

f. Tindakan pengawasan akan diteruskan dengan tindak lanjut lagi baik secara administrasi maupun secara yuridis.

Jenis pengawasan lainnya yang dapat dilakukan terhadap penyelenggaraan pemerintahan yaitu :

(i) Dari segi fungsi checks and balances system, dapat dilakukan 3 (tiga) jenis pengawasan oleh lembaga-lembaga yang berbeda yaitu:

a. Pengawasan oleh lembaga legislatif Pengawasan yang dilakukan secara khusus oleh lembaga legislatif atau parlemen. Fungsi pengawasan oleh lembaga legislatif terhadap eksekutif biasanya diatur dalam perundang-undangan yang mengatur hubungan kelembagaan kedua badan tersebut. Pengaturannya dapat diatur dalam konstitusi maupun Undang-Undang. Pengawasan yang dilakukan oleh lembaga legislatif dapat ditujukan kepada banyak hal, antara lain: segala tindakan dari pejabat eksekutif, ke-bijakan yang diambil oleh eksekutif, kinerja dari eksekutif, program dan kegiatan yang diciptakan oleh eksekutif dan penggunaan keuangan Negara oleh eksekutif.

b. Pengawasan oleh lembaga eksekutif Pengawasan ini dilakukan dalam ranah cabang kekuasaan eksekutif. Hal ini diperlukan sebab cabang kekuasaan eksekutif merupakan cabang kekuasaan yang fungsi dan wewenangnya tersebar atau didistribusikan dalam banyak ruang jabatan atau lembaga.
Kedudukan jabatan-jabatan dan lembaga tersebut dapat secara hirerarki maupun horizontal. Oleh karena itu, dalam pelaksanaan penyelenggaraan pemerintahan amat diperlukan rentang kendali, agar setiap program dan kebijakan yang diambil oleh pimpinan pun-cak tidak bergeser dari mak-sud dan tujuan atau visi dan misinya.

c. Pengawasan oleh lembaga peradilan Pengawasan ini dilakukan oleh lembaga peradilan. Pengawasan ini dilakukan oleh kekuasaan kehakiman yang secara khusus kewenangannya diatur dalam konstitusi dan peraturan perundang-undangan tentang kekuasaan kehakiman. Pengawasan ini dilakukan apabila terdapat sengketa antara pemerintah dengan pihak masyarakat. Secara teoritis, untuk hadirnya suatu peradilan diperlukan adanya beberapa unsur, yaitu : (i) adanya sengketa yang konkret; (ii) yang bersengketa minimal dua belah pihak; (iii) adanya suatu aturan hukum yang abstrak yang dapat diterapkan terhadap sengketa tersebut; (iv) adanya suatu peradilan yang mempunyai kewenangan untuk memutus sengketa hukum tersebut.

(ii) Dari segi proses dan tujuan pengawasan, yaitu :

a. Pengawasan Preventif

b. Pengawasan Refresif

(iii) Dari segi fungsi, yaitu :

a. Pengawasan Fungsional

b. Pengawasan Melekat

(iv) Dari segi kewenangannya yang digunakan untuk melakukan pengawasan, yaitu :

a. Pengawasan Politik

b. Pengawasan Yuridis

c. Pengawasan Administratif

(v) Dari segi mekanisme, yaitu :

a. Pengawasan/pengendalian langsung. 
b. Pengawasan langsung dapat juga diartikan sebagai pengawasan yang dilakukan dengan cara mendatangi langsung dan melakukan pemeriksaan di tempat terhadap objek yang diawasi.

c. Pengawasan/pengendalian tidak langsung.

Kedudukan pemerintah tidak lepas dari fungsinya dalam konteks Negara. Negera sendiri mempunyai tugas yang beragam. Tugas Negara menurut Van Vallehoven ada 4 (empat), yaitu: ${ }^{13}$

(a) Membuat peraturan dalam bentuk Undang-Undang, baik dalam arti formal maupun material yang disebut regeling.

(b) Pemerintahan dalam arti secara nyata memelihara kepentingan umum yang disebut bestuur.

(c) Mempertahankan sengketa dalam peradilan perdata yang disebut yustisi.

(d) Mempertahankan ketertiban umum baik secara preventif maupun represif di dalamnya termasuk peradilan pidana yang disebut politie.

Apabila diletakkan dalam pengertian pemerintahan dalam arti sempit yaitu eksekutif dan pemerintahan, maka fungsi pemerintahan dalam membuat kebijakan hukum dapat dikelompokkan dalam 2 (dua) jenis, yaitu:

1. Kelompok regeling adalah produk hukum tertulis yang isinya/materinya mempunyai daya ikat terhadap sebagian atau seluruh penduduk wilayah Negara.

2. Kelompok beschikking adalah produk hukum yang berupa penetapan tertulis yang diatur oleh pejabat tata usaha Negara.

Kelompok regeling termasuk dalam ruang lingkup peraturan perundang-

${ }^{13}$ Riduan, Seluk Beluk dan Asas-asas Hukum Perdata, Alumni, Bandung, 2006, hal. 150 undangan. Peraturan tersebut pada dasarnya adalah sebagai peraturan pelaksana dari Undang-Undang. Dalam tingkat pusat dapat ditemukan perarturan perundang-undangan tersebut berupa peraturan pemerintah atau peraturan presiden. Sedangkan dalam tingkat daerah terdapat peraturan daerah tingkat provinsi dan kabupaten/kota.

Dari segi fungsi, maka kewena-ngan aparat pemerintah menerbitkan produk hukum jenis peraturan perundang-undangan pada dasarnya adalah untuk mengatur kehidupan dan semua tingkah laku masyarakat. Peraturan perundang-undangan yang dikeluarkan tersebut mengikat semua atau sebagian dari masayarakat. Secara lebih rinci, fungsi dari berbagai peraturan perundang-undangan yang dibuat oleh pemerintah, yaitu :

a. Untuk mengatur kehidupan semua atau sebagian masyarakat.

b. Untuk melaksanakan perintah peraturan perundang-undangan yang lebih tinggi.

c. Untuk menjalankan fungsi pemerintah baik tingkat pusat maupun daerah

d. Sebagai instrument legal dalam melaksanakan kebijakan pemerintah bagi masyarakat.

e. Untuk melaksanakan fungsi mengatur dari pemerintah.

Sedangkan untuk kelompok beschikking dapat ditemui adanya sejumlah KTUN yang diterbitkan dalam tingkat pemerintah pusat maupun daerah. Dalam tingkat pusat dapat ditemukan adanya keputusan presiden, keputusan menteri, keputusan dirjen dan KTUN lainnya. Sedangkan di tingkat daerah dapat ditemukan juga berbagai keputusan, yaitu keputusan bupati, keputusan gubernur atau keputusan walikota.

Untuk dapat disebut sebagai peraturan perundang-undangan yang mengikat secara umum dan dibentuk atau ditetapkan oleh lembaga Negara atau pejabat yang berwenang melalui prosedur yang ditetap- 
kan dalam peraturan perundang-undangan, maka harus memiliki beberapa sifat dan ciri-ciri tertentu, yakni:

a. Harus dalam wujud peratuan tertulis

b. Harus dibentuk, ditetapkan dan dikeluarkan oleh lembaga Negara atau pejabat yang berwenang

c. Harus berisi aturan pola tingkah laku atau norma hukum

d. Harus mengikat secara umum dan menyeluruh atau bersifat abstrak dan umum.

\section{E. Kesimpulan}

1. Bentuk aspek hukum dalam pelaksanaan administrasi publik di Indonesia sebagai berikut :

a. Kebijakan publik harus dibuat tidak hanya berdasarkan prinsipprinsip ilmu admnistrasi publik, namun juga dalam ilmu hukum (perundang-undangan).

b. Kebijakan publik memiliki implykasi sosial, ekonomi dan politik.

c. Kebijakan publik akan melahirkan status hukum yang baru bagi pihak-pihak yang terkena, bisa status hukum yang positif (dalam artian memberikan hak-hak baru) atau negatif (membebankan kewajibankewajiban baru).

d. Kebijakan publik dapat ditinjau (review) tidak hanya secara sosial, politik dan ekonomi tetapi juga yuridis. Pranata pengujian (review) disediakan dengan tujuan agar penyusunan kebijakan tidak serampangan atau benar-benar mempertimbangkan dalam menyusun kebijakan agar tidak dianggap melakukan tindakan sewenang-wenang, melanggar kewenangan atau mengacuhkan kepentingan publik.

2. Fungsi pemerintah dalam membuat kebijakan dibidang hukum administrasi, dikelompokkan menjadi 2, yaitu

a. Fungsi pemerintah dalam bidang regeling adalah produk hukum tertulis yang isinya/materinya mempunyai daya ikat terhadap sebagian atau seluruh penduduk wilayah Negara.

b. Fungsi pemerintah dalam bidang beschikking adalah produk hukum yang berupa penetapan tertulis yang dibuat oleh pejabat tata usaha Negara.

\section{DAFTAR PUSTAKA}

Adrian Sutedi, Hukum Perizinan dalam Sektor Pelayanan Publik, Sinar Grafika, Jakarta, 2010

Chandra Kukathas, A Definition of the State, University of Queensland Law Journal, Australi, 2014

Dwight Waldo, Pengantar Studi Publik Administrative, Aksara Baru, Jakarta, 1991

Indoharto, Usaha Memahami Undang-Undang tentang Peradilan Tata Usaha Negara, Sinar Grafika, Jakarta, 1993

Hamzah dan Lopa, Mengenal Peradilan Tata Usaha Negara, Sinar Grafika, Jakarta, 1993

Miriam Budiardjo, Dasar-dasar Ilmu Politik, Gramedia, Jakarta, 2003

Muchsan, Sistem Pengawasan Terhadap Perbuatan Aparat Pemerintah dan Peradilan Tata Usaha Negara di Indonesia, Liberty, Yogyakarta, 1986

Philipus M. Hardjon, Pengantar Hukum Administrasi Indonesia, UGM Perss, Yogyakarta, 1994

Riduan, Seluk Beluk dan Asas-asas Hukum Perdata, Alumni, Bandung, 2006

Sosiolismanto, Hegemoni Negara Ekonomi Politik Pedesaan Jawa, Lapera Pustaka Utama, Yogyakarta, 2001

Surie, Ilmu Administrasi Negara, Gramedia, Jakarta, 1986. 
Syahran Basar, Eksistensi dan Tolak Ukur Peradilan Administrasi di Indonesia, Alumni, Bandung, 1985

Sharma, Democracy, Good Governance, and Economic Development, Journal of Democracy, Taiwan, 2007. 
Lex Librum : Jurnal Ilmu Hukum, Vol. 7 No.2, Juni 2021, hal. 151-162 